УДК 81.133.1'23

DOI https://doi.org/10.24919/2308-4863/34-5-21

Наталія ХАБАРОВА,

orcid.org/0000-0001-6108-0495

кандидат філологічних наук,

доиент кафедри романської філології

Дніпровського начіонального університету імені Олеся Гончара

(Дніпро, Украӥна) khna_80@ukr.net

Ірина ГЕТЬМАН, orcid.org/0000-0002-7974-8921

викладач кафедри романської філології Дніпровського начіонального університету імені Олеся Гончара (Дніпро, Україна) yarino4ka@gmail.com

\title{
ПСИХОЛІНГВІСТИЧНІ ТА КОГНІТИВНІ ОСОБЛИВОСТІ КОНЦЕПТУАЛЬНОЇ МЕТАФОРИ В РЕКЛАМНОМУ ТА ХУДОЖНЬОМУ ДИСКУРСАХ
}

У статті розглядається метафора як ментальна репрезентація та деякі особливості ї̈ існування в когнітивній базі індивіда з позииї сучасної когнітивної теорії. Обгрунтовується підхід щуодо вивчення метафори як частини психолінгвістичного та нейрокогнітивного континуума. Актуальність дослідження визначається відсутністю в сучасній лінгвістиці системних робіт щзодо психолінгвістичного обтрунтування особливостей творення когнітивної метафори. Мета дослідження полягає у виявленні функціонування метафори безпосередньо в ї̈̈ зв'язку з навколишнім світом шляхом виокремлення закономірностей ї̈ функиіонування. Для досягнення мети було поставлено такі завдання: 1. Дослідити метафору, пов'язану з людським фактором, яка є не лінгвістичним, а ментальним фактом і концептуалізує картину світу індивіда. 2. Проаналізувати застосування ментальних просторів щзодо дослідження метафоричного значення (або теорії концептуальної інтеграції - блендінгу). 3. Розглянути теорію нейролінгвістичних особливостей дослідження метафори, згідно з якою складні метафори утворюються від простих шляхом концептуального блендінгу.

Перетинаючи традииійні функиії виразності, метафори починають осмислюватися у зв'язку з уявною системою людини. Незважаючи на плюралізм думок, когнітивна теорія метафори далека від завершення. Вона складається зі складних блоків, розроблених у психолінгвістиці, когнітивній лінгвістиці, нейролінгвістиці та в когнітивній науиі загалом, за допомогою яких аналізуються різні аспекти иьього феномену. Когнітивний підхід та межі з психолінгвістикою й нейронаукою дають змогу представити функиіонування мови у зв'язку з навколишнім середовищем шляхом виявлення закономірностей його функціонування. Він також дозволяє описати складні проиеси передачі та обробки інформації, пов'язані з використанням метафори, які беруть участь в організаџіi знання та уявлень щзодо навколишньої дійсності й сприйняття їх індивідами.

На зміну вивченню мови як незалежної абстрактної системи знаків приходить комплексне вивчення мови, в иееттрі якої - індивід, який висловлює свої думки шляхом метафор, утворює завдяки ним світ, у якому живе. Метафора розглядається як процес, пов'язаний із людським фактором у мові, завдяки якому в мовних засобах відбивається національно-культурне багатство. Метафора є не лінгвістичним, а ментальним фактом, який кониептуалізує картину світу.

Ключові слова: метафора, ментальна репрезентація, образ метафори, блендінг, механізм творення метафори. 


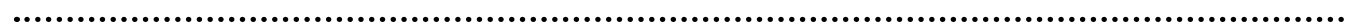

Nataliia KHABAROVA,

orcid.org/0000-0001-6108-0495

Candidate of Philological Sciences,

Associate Professor at the Department of Romance Philology

Oles Honchar Dnipro National University

(Dnipro,Ukraine) khna_80@ukr.net

\author{
Iryna HETMAN, \\ orcid.org/0000-0002-7974-8921 \\ Lecturer at the Department of Romance Philology \\ Oles Honchar Dnipro National University \\ (Dnipro, Ukraine) yarino4ka@gmail.com
}

\section{PSYCHOLINGUISTIC AND COGNITIVE FEATURES OF CONCEPTUAL METAPHORS IN ADVERTISING AND ART DISCOURSES}

\begin{abstract}
The metaphor is considered as a mental representation and some peculiarities of its existence in the individual's cognitive base from the point of view of modern cognitive theory. The approach to the study of metaphor as part of the psycholinguistic and neurocognitive continuum is determined. The relevance of the study is determined by the absence in the modern linguistics of systematic works on the psycholinguistic substantiation of the features of the creation of the cognitive metaphor. The purpose of the study is to identify the functioning of the metaphor directly in its relation to the outside world by identifying patterns of its functioning. To achieve this goal, the following tasks were set: 1. To explore a metaphor directly related to the human factor, which is not a linguistic fact, but a mental fact, and conceptualizes the picture of the world of the individual. 2. Analyze the application of mental spaces to the study of metaphorical meaning (or theory of conceptual integration - blending). 3. Consider the theory of neurolinguistic features of the study of metaphor, according to which complex metaphors are formed from simple ones through conceptual blending.

Intersecting traditional expressive functions, metaphors begin to reflect on the human imaginary system. Despite the pluralism of thought, the cognitive theory of metaphor is far from complete. It consists of complex blocks developed in psycholinguistics, cognitive linguistics, neurolinguistics and, in general, in cognitive science, through which various aspects of this phenomenon are analyzed. The cognitive approach and the boundaries with psycholinguistics and neuroscience make it possible to represent the functioning of a language directly in relation to the environment by identifying patterns of its functioning. It also describes the complex processes of transmitting and processing information related to the use of metaphors that are involved in organizing knowledge and perceptions of environmental reality and perception by individuals.

Replacing the study of language as an independent abstract system of signs comes a complex study of language, at the center of which is an individual who expresses his thoughts through metaphors, which, through metaphors, creates the world in which he lives. The metaphor is seen as a process related to the human factor in language, through which national cultural wealth is reflected in linguistic means. The metaphor is not a linguistic but a mental fact that conceptualizes the picture of the world.
\end{abstract}

Key words: metaphor, mental representation, metaphor image, blending, mechanism of metaphor creation.

Постановка проблеми. Сучасний етап розвитку наук характеризується переходом до інформаційного суспільства. В центрі уваги дослідників все частіше знаходяться механізми, за допомогою яких людина отримує та структурує інформацію. Однією з центральних тем дослідження когнітивної лінгвістики, психолінгвістики та нейронаук $€$ значення мови в таких процесах пізнання як категоризація та концептуалізація. Метафора є одним із таких механізмів.

Актуальність дослідження визначається відсутністю в сучасній лінгвістиці системних робіт щодо психолінгвістичного обгрунтування особливостей творення когнітивної метафори. Когнітивна лінгвістика - напрям, у центрі уваги якого знаходиться мова як загальний когнітивний механізм і когніція в їі мовному відбитку. Теорія метафори складаєтья зі складних концептуальних блоків, розроблених у мовознавстві, психолінгвістиці, когнітивній лінгвістиці, семіології, нейролінгвістиці, за допомогою яких аналізуються різні аспекти цього феномену.

Мета статті полягає у виявленні функціонування метафори у зв'язку із навколишнім світом шляхом виокремлення закономірностей ії функціонування. Для досягнення мети було поставлено такі завдання:

1. Дослідити метафору, пов'язану з людським фактором, яка є не лінгвістичним, а ментальним фактом і концептуалізує картину світу індивіда.

2. Проаналізувати застосування ментальних просторів щодо дослідження метафоричного значення (або теорії концептуальної інтеграції блендінгу). 
3. Розглянути теорію нейролінгвістичних особливостей дослідження метафори, згідно 3 якою складні метафори утворюються від простих шляхом концептуального блендінгу.

Під час дослідження було застосовано описовий метод, семантико-когнітивний і метод опозиції.

Аналіз досліджень. Когнітивна лінгвістка виникла в США (Дж. Лакофф, М. Джонсон (2004), М. Тернер, Ж. Фокон'є (1993), Ж. Греді (2005), Б.Діжуа(2008)таотрималазначнерозповсюдження, подальший розвиток та інтерпретацію у вітчизняній науці (Н. Д. Арутюнова (1990), Л. В. Балашова (1998) А. Н. Баранов, Д. О. Добровольський (1997), В. А. Маслов (2015), О. А. Юріна (2004).

Виклад основного матеріалу. Нині спостерігається повномасштабне повернення до аристотелівської концепції метафори як засобу світосприйняття та світорозуміння. Можливо, вперше термін «метафора» у широкому когнітивному контексті щодо вивчення психолінгвістичного й лінгвокультурного простору використали Дж. Лакофф i М. Джонсон. Учені стверджують, що будь-які перенесення мовних значень зумовлюються метафоричним мисленням людини, тобто відбуваються по заданих когнітивними метафорами моделях.

«Метафора, - пишуть Дж. Лакофф та М. Джонсон, - пронизує все наше повсякденне життя та виявляється не лише у мові, а й у мисленні та дії» (Лакофф, Джонсон, 2004). Повсякденна понятійна система, в межах якої ми мислимо та діємо, метафорична за своєю суттю: «Метафора не обмежується однією лише сферою мови, тобто сферою слів: сам процес мислення людини в значному ступені метафоричний» (Лакофф, Джонсон, 2004: 256). Це пояснюється тим, що метафора зручна для пояснення, для осмислення «далеких» один від одного понять.

Метафора здатна подолати логічно несумісні речі, для них це завдання не лише доступне, але й природнє, оскільки «метафори існують як втілення звичайного творчого процесу людського пізнання, який поєднує поняття, в нормі не пов'язані, для детальнішого занурення у суть справи» (Кормак, 1990: 373). Тому ретроспективне вивчення механізмів творення метафори безпосередньо пов' язане 3 вивченням психічних процесів, а саме 3 аналізом ментальних репрезентацій. Дослідження концептуальної метафори $є$ сферою не лише когнітивістики, лінгвістики, а й психолінгвістики, тому що до уваги беруться ментальні процеси.

Відповідно до базових постулатів когнітивної психолінгвістики дослідження механізмів метафоричної репрезентації когнітивних структур має походити 3 моделювання концептосфери конкретної мови. Так, концептуальна метафора ARGUMENT IS WAR (суперечка - це війна) споріднена 3 базовими цінностями культури носіїв англійської мови. Метафора - не стільки засіб опису суперечок у понятті «війна», скільки сталий спосіб осмислення суперечки: можна програти або виграти суперечку, опонент сприймається як супротивник, суперечники розроблюють стратегії, займають позиції, «розстрілюють» (shoot down) аргументи супротивника. Разом із тим «можна представити культуру, в якій суперечка - це танок, учасники - танцюристи, а мета полягає в гармонійному та естетичному привабливому танці, а не в перемозі над супротивником. Концептуальні метафори «є незмінною частиною культурної парадигми носія мови та психологічного сприйняття ситуації» (Лакофф, Джонсон, 2004: 256). Вони вкорінені у свідомості людей і настільки звичні, що часто навіть не усвідомлюються як метафори:

У типології американських дослідників концептуальні метафори поділяються на три основні групи: структурні, онтологічні та орієнтаційні. У структурних метафорах когнітивна типологія сфери-мішені є моделлю для осмислення сферимішені (ARGUMENT IS WAR), онтологічні метафори категоризують абстрактні сутності шляхом окреслення їхніх меж у просторі (MIND IS MACHINE) або за допомогою персоніфікації (Inflation is eating up our profits), орієнтаційні метафори відбивають опозиції, в яких зафіксовано наш досвід просторової орієнтації у світі (GOOD IS UP, BAD IS DOWN).

Відповідно до теорії концептуальної метафори в основі метафоризації лежить процес взаємодії між структурами знань (фреймами та сценаріями) двох концептуальних доменів - сфери-джерела (source domain) та сфери мішені (target domain). У результаті односкерованої метафоричної проекції (metaphorical mapping) зі сфери-джерела у сферу-мішень, сформованих у результаті досвіду взаємодій людини з навколишнім світом, елементи сфери-джерела структурують менш зрозумілу концептуальну сферу-мішень, що складає сутність когнітивного потенціалу метафори.

Базовим джерелом знань, які складають концептуальні домени, є досвід безпосередньої взаємодії людини з навколишнім світом. Першим $\epsilon$ фізичний досвід у діахронічному плані, який категоризує дійсність у вигляді простих когнітивних структур - «схем-образів». Метафорична проекція здійснюється між концептуальними структурами доменів, а не лише між окремими елементами двох структур. Припущення про те, що під час метафоричної проекції у сфери-мішені част- 
ково зберігається структура сфери-джерела отримало назву гіпотези інваріативності в роботі Дж. Лакоффа та М. Джонсона «Метафори, якими ми живемо» (2004). Завдяки цій властивості стають можливими метафоричні наслідки, які в метафоричному виразі експліцитно не виявляються, але виводяться на базі фреймового знання. Тобто типологія сфери-джерела в якійсь мірі визначає спосіб осмислення сфери-мішені фреймового знання та $є$ основою для прийняття рішень і дій.

Особливого розповсюдження отримали дослідження концептуальної метафори. Нині серед дослідників спостерігається широке розповсюдження когнітивного потенціалу метафори в отриманні наукового знання. Вплив концептуальної метафори на отримання наукових ідей досліджувався відповідно до філософії, політики, генетики, психології та інших наук. Велику цікавість теорія концептуальної метафори викликала у дослідників психолінгвістичного напряму. Головний сумнів серед психолінгвістів викликало питання стосовно того, чи супроводжується актуалізація стертих метафор активними операціями над концептуальними доменами, чи не пасивно засвоюється вона носіями мови.

Цікавий експеримент щодо верифікації припущення Дж. Лакоффа про «тілесний розум» і підсвідомий характер базових концептуальних метафор було проведено в Каліфорнійському університеті Р. В. Гіббсом і Н. Л. Вілсоном (Гіббс, 2002). Під час експерименту було встановлено кореляції між моторикою піддослідних і вживанням антропоморфних метафор. При цьому кореляція не варіювалася залежно від національності піддослідних (в експерименті брали участь носії англійської та португальської мов). У цій публікації автори розглядають дослідження, яке підтверджує зв'язок між активацією частин головного мозку, які відповідають за моторику, та лінгвістичними виразами, пов'язаними з тілесним досвідом взаємодії 3 навколишнім світом.

Психолінгвістичні методи дослідження метафори дозволяють отримувати дані щодо особливостей розуміння навколишнього світу індивідом, що недоступно при традиційному аналізі (Фрумкіна, 2001), щодо специфіки ії функціонування в індивідуальному лексиконі (Залевська, 2005; Лєбєдєва, 2006). На думку О. В. Улибіної, «процес формування діяльності, описаний А. Н. Лєонт'євим, у деяких структурних моментах близький до того, як представлено процес розвитку психіки в теорії Ж. Лакана. Основним моментом, який визначає близькість, є використання обома авторами (в явній формі у Лакана та неявній у Лєонт'єва) моделі метафори» (Улибіна, 2006: 205). Відповідно до теорії діяльності сполучення предмета та потреби утворює структуру, яка відповідає структурі метафори - одне означуване та кілька означуваних, пов'язаних за принципом схожості.

На думку О. В. Улибіної, первинне означуване в природі не існує, а людина, яка живе в культурному середовищі, завжди має справу 3 переробленими культурою речами (Улибіна, 2006). До того ж метафори виступають зовнішніми образами свідомості, більшість із яких має культурну специфіку. Ті ж мовні засоби «перекручують образи свідомості в їх зовнішній інтерпретації» (Сергієва, 2009: 3).

Психолінгвістичний підхід, на нашу думку, вдало синтезує розглянуті концепції та дозволяє в якійсь мірі зняти розбіжності в проблемах вивчення метафори. Предметне значення втілюється у слові шляхом багаторазового вживання в схожих ситуаціях, закріплюється в найбільш типових сполучуваних конструкціях. Тому метафора, як і будь-яке слово, коли перетворюється в сталий вираз на основі «порівняння того, що не можна порівняти», втілює істотні сторони дійсності, базується на інваріантних відношеннях між раціональним і чуттєвим.

Відповідно до концепції втілення А. А. Залевської (2005), лексема (як і метафора) є своєрідним ключем до умовно-дискретного фрагменту континуальної та багатомірної індивідуальної картини світу, повнота якої забезпечується вихідними знаннями та хвилюваннями різних видів. На відміну від традиційного підходу до метафори, психолінгвістична теорія значення визнає початкову динамічність того, що в носія мови відбувається ув'язка 3 формою будь-якої вербальної одиниці, що забезпечує сприйняття цієї одиниці як знайомої, зрозумілої при постійній взаємодії свідомого та несвідомого, вербального та непідвладного вербалізації, при притаманному людині акцентуванні уваги й різних ознак (Залевська, 2005).

Саме тому когнітивний підхід щодо дослідження метафори не обмежується теорією концептуальної метафори. Нині когнітивні лінгвісти не поділяють думки щодо домінантності двокомпонентної моделі метафори. Як зазначають Є. В. Будаєв та А. П. Чудінов, з середини 90-х років минулого століття розвивається альтернативний підхід щодо аналізу когнітивної метафори, відомий як теорія концептуальної інтеграції, або теорія «блендінгу» (Будаєв, Чудінов, 2008). Теорія концептуальної інтеграції (теорія блендінгу) розвивається у працях Дж. Бран- 
дена (2004), М. Тернера та Ж. Фокон'є (1993). Йдеться про змішання «концептів». Як зазначає А. Річардс, «при використанні метафори у нас присутні дві думки про дві різні речі, при цьому думки взаємодіють між собою всередині одного слова або виразу, чиє значення і є результатом цієї взаємодії» (Річардс, 1990).

У запропонованій теорії М. Тернер і Ж. Фокон'є (1993) дійшли висновку, що метафоризація не вичерпує проекцію зі сфери-джерела у сферу-мішень, як у концептуальній теорії метафори, а складається зі складних інтеграційних процесів. Вони утворюють змішані ментальні процеси, які здатні в процесі концептуальної інтеграції вибудовувати структуру значення. М. Тернер і Ж. Фокон'є (1993) запропонували альтернативну двохдоменної моделі метафори модель кількох просторів. На їх думку, односкерована метафорична проекція зі сфери-джерела у сферу-мішень $є$ лише приватним випадком більш складного, динамічного та варіативного комплексу процесів, для експлікації яких вчені вводять у дослідження когнітивної метафори два проміжних простори (middle spaces). На відміну від теорії Дж. Лакоффа та М. Джонсона щодо двох концептуальних доменів, розглядається чотири ментальних простори: два початкових простори (input spaces), загальний простір (generic space) i змішаний простір (blended space), або бленд (blend). Початкові простори співвідносяться зі сферою-джерелом і сферою-мішенню в теорії концептуальних просторів, хоча кількість початкових просторів може перевищувати два.

Ментальні простори не тотожні концептуальним доменам. Ментальний простір - це відносно невеликий «концептуальний пакет», який частково запозичується 3 концептуального домену. Конструюється лише частина структури для розуміння конкретної ситуації або дії. Щодо метафори, то дослідники часто використовують наукове поняття-бленд «початковий домен» (input domain), яке поєднує ідеї теорії концептуальної метафори та концептуальної інтеграції.

Загальний простір містить найбільш абстрактні елементи (ролі, фрейми, схеми), які притаманні обом початковим просторам, тобто є базою для метафоризації на абстрактному рівні. У бленді «змішуються» деталі початкових просторів, в результаті чого утворюється нова концептуальна структура. Вона більше не залежить від початкових просторів і має свої потенції для подальшого розвитку. Такий підхід можна продемонструвати на прикладі реклами французького автомобіля: "Au volant de cette vioture vous imagineriez le pilote
Formule 1 et s'en volez en haut au ciel” («За кермом цієї машини ви відчуваєте себе пілотом формули 1 та злітаєте високо в небо»).

У дослідженому бленді виконується інтеграція двох початкових ментальних просторів, в яких покупець співвідноситься 3 пілотом Формули 1, а машина - із птахом або літаком. Бленд запозичує фреймову структуру як у слова «пілот» (має здібності в керуванні, хист, швидко пристосовується під обставини шляху, може їхати дуже швидко), так і казуальну, дійову структуру з відомих дій (автомобілі «літають», наче птахи, наче літаки). В розглянутому прикладі загальний простір містить один об'єкт, який занурений у дію, спокушається до мети (відчувати себе на висоті) та який має переваги для іншого об'єкту (для майбутнього покупця). Очевидно, що в загальному просторі результат відчуття бути пілотом цілком ймовірний для кожного, хто стане власником такої машини.

Міждоменнапроекція маєметафоричний характер, але змішаний простір має казуально-подвійну структуру, яка не виводиться із фрейму-джерела. Якщо метафоричні інференції виводити лише 3 ментального простору-джерела, то пілотом може стати кожен, а не лише власник саме цієї машини, що рекламується. Отримана інференція не виводиться $з$ простору-мішені. У бленді з'являється нова структура, оскільки літати може птах або літак, але «літати» на автомобілі може лише пілот, власник цього автомобілю, тобто той, хто за кермом. Ця «можлива» структура не підсильна 3 початкових структур, вона конструюється у бленді та приносить нові змісти, понятійні інференції.

На думку вчених, у теорії блендінгу процес концептуальної інтеграції відбувається у три етапи: композиція (composition), оформлення та розробка (completion та elaboration) (Греді, 2005). На етапі композиції зміст початкових просторів проектується у змішаний простір. Він сприймається при оформленні як довгострокова єдина концептуальна структура, яка може безкрайньо змінюватися та розроблятися.

Аналізуючи метафори, дослідники блендінгу часто стикаються 3 інтеграційними мережами (integration networks). Вони містять кілька початкових просторів з різними видами проекції (наприклад, метонімію та метафору) (Тернер, 1993). На базі аналізу мережевих структур М. Тернер і Ж. Фокон'є розробили принципи оптимальності інтеграційних мереж:

1. Принцип інтеграції. Змішаний простір має утворювати жорсткий змішаний простір, яким можна оперувати як єдиним цілим. 
2. Принцип мережі. Маніпуляції блендом мають підтримувати мережу відповідних зв'язків із початковими просторами без додаткових спостережень.

3. Принцип розпакування. Цей бленд має дозволити реконструювати початковий простір, міждоменну проекцію, загальний простір і мережу зв'язків між всіма просторами.

4. Принцип топології. Кожен елемент у бленді має функціонувати відповідно до структурних відносин, притаманних початковому простору.

5. Принцип відповідної бази. Якщо елемент 3'являється у бленді, то з'являється необхідність уваги для цього елементу. Значущість має релевантні зв'язки з іншими просторами та релевантні функції, залучені у бленді.

6. Принцип зменшення метонімічної дистанції. Якщо один елемент проектується 3 початкового простору у бленд, а інший елемент 3 того ж простору проектується завдяки метонімічному зв'язку, то зменшується метонімічна дистанція між обома елементами (Тернер, Фокон'є, 1993).

Так, у метафорі: La télé comme point de départ (voyage TV) (Телебачення як місие відліку (телебачення подорожей) деталі інтеграційної мережі розроблюються у самому бленді, а не виводяться 3 метафоричної проекції. Якщо відношення телебачення як подорожі метафоричне, то відношення подорожі та місце відліку метонімічне. За принципом метонімічного звуження місце відліку більше зв'язано у бленді, ніж в початковому просторі-джерелі. Зазначимо, що місце відліку символізує початок чогось нового та асоціюється 3 крапкою нерухомості. У бленд також проектуються математичні підрахунки у поєднані з філософськими міркуваннями.

Важливо мати на увазі, що блендінг розуміється досить розповсюджено та не обмежується процесами метафоризації: його значущість у когнітивних процесах майже загальна. Теорія концептуальної інтеграції та теорія простих і складних метафор (Греді, 2005) вплинули на становлення нейрокогнітивного підходу. Відповідно до дослідження Дж. Е. Греді, метафори поділяються на первинні (primitive) та складні (complex). Формування первинних метафор відбувається на ранніх стадіях онтогенезу в період так званої фази «конфляції», коли суб'єктний і сенсорно-моторний досвід ще не поділилися. Когнітивні зв'язки, встановлені в цей період, зберігають і виявляють себе протягом усього життя людини й слугують основою для формування складних метафор. Вони утворюються 3 первинних шляхом концептуального блендінгу. Складні метафори, так само як і первинні, пов'язані зі сенсомоторною діяль- ністю. Будь-яке осмислення, фігуративні зв'язки $\epsilon$ не лише метафоричними, а й метонімічними. Тобто метафоричні відносини всередині складних метафор можуть бути відправними крапками для процесу творення складних концептуальних мереж (Греді, 2005).

На довербальному етапі виникнення концептуальної метафори базову роль відіграють нейросеміотичні процеси, які наша свідомість експлікує та сприймає, але які сховані від зовнішнього сприйняття, від зв'язків несумісних об'єктів. На вербальному рівні вони репрезентуються словесними метафорами або фразеологічними одиницями типу океан (про нескінченне та безмежне явище). У давньофранцузькій літературі незбагненні речі порівнювали 3 океаном: l'océan des pensées, l'océan des soldats, l'océan des secrets. Той самий зміст вкладають письменники реалізму: «Mais Paris est un véritabe ocean. Jetez-y la sonde, vous n'en connaîtrez jamais la profondeur. Parcourez-le, décrivez-le! quelque soin que vous mettiez à le parcourir, à le décrire; quelque nombreux et intéressés que soient les explorateurs de cette mer, il s'y rencontrera toujours un lieu vierge, un antre inconnu, des fleurs, des perles, des monstres, quelque chose d'inouï, oublié par les plongeurs littéraires». Ici, dans «Le père Goriot», Balzac compare Paris à un océan. Такі метафори вишукані, в одній фразі, кожна $з$ них виявляє деталі цілого, наповненого перетвореного світу.

Для нейрокогнітивного підходу досить плідними є ідеї К. Г. Юнга, засновника аналітичної психології щодо символіко-архетипічного характеру людської психіки, який визначає здатність метафори зумовлювати «побудову» цільної картини навколишнього середовища (Jung, 1996). Архетип надає почуття предметності відчуттям людини в символічній та міфологічній формі. Описані К. Юнгом різновиди архетипів є формоутворювальними елементами сприйняття, які зумовлюють його можливість і $є$ результатом спонтанного народження образів. Ці образи виступають інваріантними для всіх людей нейродинамічними структурами мозку. Лінгвісти стверджують, «що архетипи зумовлюють важливі уявлення людства про цілісність світу та свого місця в ньому. Ми вважаємо, що саме архетипи є прототипами усіх метафор, свого роду метафоричними прообразами, що метафори слід розглядати у зв'язку з символікоархетипною основою свідомості» (Полозова, 58).

Ми усвідомлюємо той факт, що метафора первинно починається як первинна метафора або інша проста концептуальна асоціація для того, щоб стати базою частини концептуальної 
інтеграції. Первинне поняття будь-якої складності метафори може викликати побудову більш складного образу. Поряд із цим роль складних метафор у концептуальному блендінзі ілюструє важливий принцип в межах концептуального комплексу та всієї інтеграційної концептуальної мережі. В основі цього поняття складається безліч різних специфічних метафоричних зв'язків, образ яких загалом не має накладення однієї початкової області на іншу. Інтеграційні мережі не $\epsilon$ сталими, попередньо наявними конвенційними структурами. Ментальний, а не мовний феномен все частіше ініціює звернення вчених до психолінгвістичного складника при аналізі метафори, яка розглядає людину, «занурену в стихію» мови. Дослідження цієї парадигми скеровані на вивчення ролі метафори у мовленнєвої діяльності, на вивчення iï психологічних і нейропсихологічних аспектів.

Отже, блендінг - це когнітивний механізм, який опановує різні когнітивні феномени, в тому числі категоризацію, побудову гіпотез, інференцію, походження та комбінування граматичних конструкцій, аналогії, метафору, психологічні аспекти дослідження метафори. Як видно з визначення, в теорії блендінгу метафора займає місце лише одного 3 когнітивних механізмів або різновидів загального механізму концептуальної інтеграції.

У найбільш загальному вигляді пропонується вважати метафоричним такий змішаний простір, у якому концептуальна інтеграція супроводжується фузією (fusion) елементів початкового простору. Так, бленд Le poids des mots, le choc des photos (Paris Match) (Вага слів, шок фотографiü) складається $з$ деякого сплаву, слово є важливим і співвідноситься 3 концептом ваги, 3 концептом журналу в початкових просторах, у той час, коли в неметафоричних блендах один елемент співвідноситься лише 3 одним початковим простором. Необхідно зазначити, що в рекламній комунікації один із концептів не завжди називається напряму, він рекламується та мається на увазі, як у зазначеному вище прикладі.
Підкреслимо, не можна говорити про розбіжності в досліджених теоріях (концептуальна метафора та теорія концептуальної інтеграції) на загальнотеоретичному рівні. Вони об'єднані загальним поглядом на онтологічний статус та епістемологічну роль метафори. При вивченні традиційної теорії Дж. Лакоффа необхідно враховувати ідеї загальної теорії блендінгу.

Дослідники блендінгу аналізують одиничні приклади (здебільшого свіжі метафори), однак корпусних досліджень метафори в рамках цієї теорії не відбувалося. Очевидно, що це пов'язано 3 великою практичною складністю корпусного опису концептуальних інтеграційних мереж (унікальних для кожного конкретного випадку) та відсутністю відповідної методики. Дослідники блендінгу розпочали спробу відбити динаміку метафоризації та звернулися до аналізу поодиноких прикладів. Однак подолання статичного ракурсу в розгляді метафоричних відповідностей дуже ускладнило корпусний опис узгоджених із визначеною культурою метафоричних моделей. Тому нові дослідження були отримані внаслідок відмови від старих. Важливо враховувати, що дослідники блендінгу ставлять перед собою інші цілі: вивчити метафору не як культурно-статичний, а як індивідуально-динамічний феномен 3 позиції сприйняття іï індивідами.

Висновки. Проведений аналіз свідчить про формування в когнітивній парадигмі на сучасному етапі розвитку оригінальної методологічної системи, яка містить 3 головні підходи (концептуальний, психолінгвістичний і нейрокогнітивний). Вони збагачують когнітивну теорію, оскільки кожен метод має свої переваги та дозволяє виявити деякі факти й закономірності, які не привертали раніше уваги дослідників, що в комплексі створює умови для повного та багатоаспектного дослідження природи метафори. Підкреслимо, що не можна говорити про розбіжності на загальнотеоретичних рівнях, до того ж не завжди можна провести меж між підходами. Дослідження інтегративного підходу, який поєднує сучасні проблеми метафори, може бути темою для подальшого дослідження.

\section{СПИСОК ВИКОРИСТАНИХ ДЖЕРЕЛ}

1. Арутюнова Н. Д. Вступительная статья. Теория метафоры. Москва. 1990. С. 5-32.

2. Балашова Л. В. Метафора в диахронии (на материале русского языка XI - XX веков). Монография. Саратов : СГУ. 1998. $216 \mathrm{c}$

3. Баранов А. Н., Добровольский Д. О. Постулаты когнитивной семантики. Известия АН. Серия: Лит. и яз. 1997. Т. 56. № 1. С. 11-21.

4. Будаев Э. В. Зарубежная политическая метафорология : монография / Э. В. Будаев, А. П. Чудинов. Екатеринбург. 2008. $248 \mathrm{c}$.

5. Залевская А. А. Психолингвистические исследования. Слово. Текст. Избранные труды. Москва. 2005. 542 с.

6. Лакофф Д. Метафоры, которыми мы живем / Д. Лакофф, М. Джонсон; пер. с англ.; под ред. А. Н. Баранова. Москва. 2004. 256 c. 
7. Лебедева С. В. Медицинская метафора в современном языке : монография. Курск. 2006. 128 с.

8. Мак Кормак Э. Когнитивная теория метафоры. Теория метафоры. Москва. 1990. С. 358-386.

9. Маслова В. А. Введение в когнитивную лингвистику. Москва. 2015. 296 с.

10. Полозова И. В. Метафора как средство философского и научного познания. М., 2003. URL: http://diss.rsl.ru/ diss/03/1076/031076044.pdf.

11. Ричардс А. Философия риторики. Теория метафоры. Москва. 1990. С. 44-67.

12. Сергиев Н. С. Хронотоп жизненного пути в русском языковом сознании. Автореф. дис. доктора филол. наук. Москва. 43 с.

13. Улыбина Е. В. Метафора и деятельность: предмет потребности как метафора. Психологическая теория деятельности: вчера, сегодня, завтра. Москва. С. 205-214.

14. Фрумкина Р. М. Психолингвистика. Москва, 2001.23 с.

15. Юрина Е. А. Лексическая образность по данным психолингвистических экспериментов. Вестник Томск. гос. ун-та. Томск. 2004. № 38. С. 107-138.

16. Barnden J. A. Varieties and directions of interdomain influence in metaphor. Metaphor and Symbol. 2004. Vol. 19. № 1. C. 1-30.

17. Dijoua B. Modélisation informatique d'une base de connaissance lexicales (2008).

18. (DiSSc) Réseaux polisémiques et schèmes sémantico-cognitifs. Thèse de doctorat. Sorbonne. 486 p.

19. Gibbs R. W. Bodily action and metaphorical meaning. Style. 2002. Vol. 36. P. 524-540.

20. Grady J. Foundations of meaning: primary metaphors and primary scenes. Pragmatics. V. 37. 2005. Issue 10. P. $1595-1614$.

21. Jung C. G. Métaphores de l'âme et ses symboles. Paris. 1996.346 p.

22. Turner M. Metaphor, Metonymy and Binding. P. 2002. 477-478.

\section{REFERENCES}

1. Arutyunova N. D. Vstupitelnaya statya. Teoriya metafory. [Introductory article. Metaphor theory]. Moskva. 1990. 5-32 [in Russian].

2. Balashova L. V. Metafora v diahronii (na materiale russkogo yazyka XI - XX vekov). [Metaphor in diachrony (based on the Russian language of the $11^{\text {th }}-20$ th centuries)]. Monografiya. Saratov : SGU. 1998. 216 p. [in Russian].

3. Baranov A. N., Dobrovolskij D. O. Postulaty kognitivnoj semantiki. [Postulates f cognitive semantics]. Izvestiya AN. Ser. lit. i yaz. 1997. T. 56. № 1. 11-21 [in Russian].

4. Budaev E. V. Zarubezhnaya politicheskaya metaforologiya : monografiya / E. V. Budaev, A. P. Chudinov. [Foreign political metaphorology : monograph]. Ekaterinburg. 2008. 248 p. [in Russian].

5. Zalevskaya A. A. Psiholingvisticheskie issledovaniya. Slovo. Tekst. [Psycholinguistic research. Word. Text]. Izbrannye trudy. Moskva. 2005. 542 p. [in Russian].

6. Lakoff D. Metafory, kotorymi my zhivem / D. Lakoff, M. Dzhonson; per. s angl.; pod red. A. N. Baranova. [The Metaphors We Live By]. Moskva. 2004. 256 s. [in Russian].

7. Lebedeva S. V. Medicinskaya metafora $v$ sovremennom yazyke : monografiya. [Medical metaphor in modern language : monograph]. Kursk. 2006. 128 s. [in Russian].

8. Mak Kormak E. Kognitivnaya teoriya metafory. Teoriya metafory. [Cognitive metaphor theory]. Moskva. 1990. 358-386 [in Russian].

9. Maslova V. A. Vvedenie v kognitivnuyu lingvistiku. [Introduction to Cognitive Linguistics]. Moskva. 2015. $296 \mathrm{s.}$ [in Russian].

10. Polozova I. V. Metafora kak sredstvo filosofskogo i nauchnogo poznaniya. [Metaphor as a means of philosophical and scientific knowledge]. M., 2003. URL: http://diss.rsl.ru/diss/03/1076/031076044.pdf [in Russian].

11. Richards A. Filosofiya ritoriki. [Philosophy of rhetoric]. Teoriya metafory. Moskva. 1990. 44-67 [in Russian].

12. Sergiev N. S. Hronotop zhiznennogo puti v russkom yazykovom soznanii. [Chronotope of the life path in the Russian language consciousness]. Avtoref. dis. doktora fil. nauk. Moskva. 2009. 43 s. [in Russian].

13. Ulybina E. V. Metafora i deyatelnost: predmet potrebnosti kak metafora. [Metaphor and activity: the subject of need as a metaphor]. Psihologicheskaya teoriya deyatelnosti: vchera, segodnya, zavtra. Moskva. 2006. 205-214 [in Russian].

14. Frumkina P. M. Psiholingvistika. [Psycholinguistics]. Moskva. 2001. 23 s. [in Russian].

15. Yurina E. A. Leksicheskaya obraznost po dannym psiholingvisticheskih eksperimentov. [Lexical imagery according to psycholinguistic experiments]. Vestnik Tomsk. gos. un-ta. Tomsk. 2004. № 38. 107-138 [in Russian].

16. Barnden J. A. Varieties and directions of interdomain influence in metaphor. Metaphor and Symbol. 2004. Vol. 19. № 1. 1-30.

17. Dijoua B. Modélisation informatique d'une base de connaissance lexicales. 2008.

18. (DiSSc) Réseaux polisémiques et schèmes sémantico-cognitifs. Thèse de doctorat. Sorbonne. $486 \mathrm{p}$.

19. Gibbs R. W. Bodily action and metaphorical meaning. Style. 2002. Vol. 36. 524-540.

20. Grady J. Foundations of meaning: primary metaphors and primary scenes. Pragmatics. 2005. V.37. Issue 10.1595-1614.

21. Jung C. G. Métaphores de l'âme et ses symboles. Paris. 1996. 346 p.

22. Turner M. Metaphor, Metonymy and Binding. 2002. 477-478. 